\title{
Evaluation of in vitro percutaneous enhancement effect of papain and pequi oil on diclofenac sodium permeation through human skin
}

\author{
Patrícia Santos Lopes', Claudinéia Aparecida Sales de Oliveira Pinto ${ }^{2}$, André Rolim Baby ${ }^{2 *}$, Maria \\ Valéria Robles Velasco², Maria Elena Taqueda ${ }^{3}$, Telma Mary Kaneko²
}

${ }^{1}$ Faculty of Pharmacy, Sorocaba University, ${ }^{2}$ Department of Pharmacy, Faculty of Pharmaceutical Sciences, University of São Paulo, ${ }^{3}$ Polytechnic School, University of São Paulo

*Correspondence:

A. R. Baby

Department of Pharmacy

Faculty of Pharmaceutical Sciences

University of São Paulo - FCF-USP

Av. Prof. Lineu Prestes, n. 580 - BI. 13

Conjunto das Químicas - Cidade

Universitária

05508-900 - São Paulo- SP, Brazil

E-mail: andrerb@usp.br;

andre_rolim@uol.com.br
The purpose of this research was to determine the potential of papain and pequi oil as penetration enhancers for diclofenac sodium (DS) across human skin in vitro. The permeation studies were conducted with vertical diffusion cells. The enhancers were associated or not in gels in different concentrations. In vitro studies reveled that papain $0.2 \%(w / v)$ presented an elevated enhancer property for diclofenac sodium $\left(J=0.3369 \mu \mathrm{g} / \mathrm{cm}^{2} x \mathrm{~h}\right)$. Pequi oil $10 \%(w / v)$ generated a reduced flux value $\left(J=0.1848 \mu \mathrm{g} / \mathrm{cm}^{2} x h\right)$ and a combination of both enhancers presented a medium value of $J=0.2187 \mu \mathrm{g} / \mathrm{cm}^{2} x \mathrm{~h}$. Papain was found to be better enhancer than pequi oil.

\section{INTRODUCTION}

The skin has been shown as a suitable delivery route for drugs formulated in transdermal therapeutic systems (TTS). Many strategies have been suggested in order to overcome the low permeability of drugs through the skin. One of them has been to include penetration enhancers in formulations. These substances remove reversibly the barrier resistance of the stratum corneum and permit the access of the drug to the viable tissues and systemic circulation (Barry, 2001). Different substances have been used for this purpose, including terpens and oleic acid (Escribano et al., 2003).

The aim of this research work was to determine the potential of papain and pequi oil, as penetration enhancers in the percutaneous absorption of drugs. Diclofenac sodium (DS) has been used as model drug due to its hydrophilic characteristic that is not easily absorbed upon transdermal application (Nishihata et al., 1988; Escribano et al., 2003). Papain $(\mathrm{P})$ is a sulfhydryl protease from Carica papaya latex. This proteolytic enzyme has been used in the treatment of large skin lesions by its ability to remove injured tissues and to stimulate the cicatrisation process. Papain has been used before as a keratolytic substance to improve the delivery of antimycotic drugs through human nail (Quintanar-Guerreiro et al., 1998; Pinto et al., 2007). Pequi oil (PO) is extracted from pequi, Caryocar brasiliense a typical Brazilian fruit, which is rich in oleic acid (about $50 \%$ ), and it has been used in cosmetic formulations as an emollient agent. However, the action as penetration enhancer of the association of papain and pequi oil has not been investigated yet.

On the other side, the current trend is a revival of the interest in the use of natural products in pharmaceutical products and dosage forms. The general public are using natural raw materials or botanical extracts in many ways, 
such as conventional and complementary therapies, and also the pharmaceutical industry, as a source of new lead molecules for using as drug or as ingredients to formulations. Therefore the natural products offer a vast, virtually untapped reservoir of chemical compounds with many potential uses (Rolim et al., 2006; Baby et al., 2007).

\section{MATERIAL AND METHODS}

\section{Material}

Henrifarma (Brazil) supplied diclofenac sodium $(99,9 \%)$. Pequi oil was obtained from Farma Service - Ion Química (Brazil). Papain, 30000 USP-U/mg, was obtained from Merck (Germany). All the materials and reagents were of pharmaceutical or analytical grade without any further purification.

\section{Membrane preparation}

Human skin, obtained from breast reduction plastic surgery with dermatome targeted to 500 micrometers was supplied by Hospital of São Paulo, São Paulo, Brazil. Skins samples were obtained from Afro-Brazilian and Caucasian women aging from 20 to 48 years old. Samples were immediately placed in Eagles Minimum Essential Medium (MEM) with Earle's Balanced Salt Solution (BSS) and gentamicin $50 \mathrm{mg} / \mathrm{mL}$, supplied by Gibcobrl. The skin was stored at $4.0 \pm 0.5^{\circ} \mathrm{C}$ in this medium during 24 hours . On the day of the experiment, the skin was washed and immediately used for the diffusion (permeation) studies. This experiment was carried out under approval of Ethic Committee of School of Pharmaceutical Sciences of University of São Paulo (FCF-SP).

\section{Gel Formulation}

An aqueous gel formulation was used to evaluate the enhancer properties of papain and pequi oil. DS was added to an acrylic polymer hydrophilic gel (Carbopol ${ }^{\circledR}$ Ultrez
10). Pequi oil was tested at two different concentrations, $5 \%$ and $10 \%$, and papain at $0.2 \%$ and $0.05 \%$. In addition, a combination of substances, pequi oil $7.5 \%$ and papain $0.1 \%$, was tested (Table I).

\section{Permeation Studies}

The permeation studies were carried out on Franz-type diffusion cells with a diffusion area of $1.651 \mathrm{~cm}^{2}$. Three Franz cells were mounted in a Multistirrer - IUCHI system and placed in a thermostatic bath at $37.0+0.5^{\circ} \mathrm{C}$. The skin membranes were first cleaned with MEM-BBS with gentamicin, which also served as receptor fluid in the receptor compartment. Approximately $0.5 \mathrm{~g}$ test gel was placed on the donor side. At predetermined time intervals, $600 \mathrm{~mL}$ samples were withdrawn from the receiver compartment and an equal volume of fresh medium was replaced to maintain constant volume. Diclofenac sodium was determined by HPLC previously validated (Lopes et al., 2003).

HPLC analyses were undertaken using a Shimadzu LC-10 AD equipped with three pumps, Detector-UV -VIS - Shimadzu SPD -10A, Shimadzu Auto Injector-SIL- 10A and software Class - LC10 (version 1.61). A reversedphase column ( $25 \mathrm{~cm} \times 4.5 \mathrm{~mm}$ I.D.) packed with Econosil C18 (5 mm) was used with precolumn Econosil C18 $(7 \mathrm{~mm})$. Samples were injected in a volume of $15 \mathrm{~mL}$ and detected at $283 \mathrm{~nm}$. The mobile phase consisted of methanol: acetic acid $3 \% \mathrm{v} / \mathrm{v}$ water solution $(74: 26)$ and was run at $1 \mathrm{~mL} / \mathrm{min}$. Various concentrations of DS in MEM-BBS with gentamicin were used to construct the standard curve, one for each experiment. All studies were conducted using the infinite-dose technique and the permeation data from the in vitro experiment was analyzed using the lag time method. In addition, the experiments were carried out for $56 \mathrm{~h}$, requiring at least three lag times to achieve a steady-state flux (Shah, 1993; Shah et al., 1994). The parameters estimated using the lag time method were the steady-state flux $(\mathrm{J})$, permeability coefficient $(\mathrm{P})$, Lag Time (Tlag), diffusion coefficient (D) and skin/donor phase partition coefficient $(\mathrm{K})$.

TABLE I - Gel formulations.

\begin{tabular}{lcccccc}
\hline Formulations & Analyte-free & 1 & 2 & 3 & 4 & 5 \\
\hline Carbopol $^{\circledR}$ Ultrez 10 (w/w) (\%) & 0.5 & 0.5 & 0.5 & 0.5 & 0.5 & 0.5 \\
Diclofenac sodium (w/w) (\%) $_{\text {Pequi oil (w/v) (\%) }}^{1.5}$ & 1.5 & 1.5 & 1.5 & 1.5 & 1.5 \\
Papain (w/w) (\%) & - & 5 & 10 & - & - & 7.5 \\
Cystein (w/w) (\%) & - & - & - & 0.2 & 0.05 & 0.1 \\
Purified Water q. s. to (g) & - & - & - & 0.04 & 0.01 & 0.02 \\
\hline
\end{tabular}


TABLE II - Percutaneous penetration values of flux, permeability coefficient, Lag Time, Diffusion coefficient, Partition Coefficient and type of skin used in fourteen experiments.

\begin{tabular}{lcccccc}
\hline $\begin{array}{l}\text { Formulation } \\
\text { (Treatment) }\end{array}$ & $\begin{array}{c}\text { Volunteer } \\
\text { (age, race) }\end{array}$ & $\mathrm{J}\left(\mu \mathrm{g} / \mathrm{cm}^{2} \mathrm{xh}\right)$ & $\begin{array}{c}\mathrm{P}(\mathrm{cm} / \mathrm{h}) \\
(\mathrm{x} \mathrm{10})\end{array}$ & $\mathrm{Tlag}(\mathrm{h})$ & $\begin{array}{c}\mathrm{D}\left(\mathrm{cm}^{2} / \mathrm{h}\right) \\
\left(\mathrm{x} 10^{-3}\right)\end{array}$ & $\mathrm{K}\left(\mathrm{x} 10^{-6}\right)$ \\
\hline 1 & 32, Afro Brazilian & 0.2905 & 1.94 & 12.155 & 3.43 & 2.825 \\
& 33, Caucasian & 0.1627 & 1.08 & 9.229 & 4.51 & 1.201 \\
2 & 30, Caucasian & 0.2132 & 1.42 & 8.757 & 4.76 & 1.494 \\
3 & 48, Afro Brazilian & 0.1921 & 1.28 & 10.410 & 4.0 & 1.63 \\
& 43, Afro Brazilian & 0.1774 & 1.18 & 5.160 & 8.07 & 0.732 \\
& 39, Caucasian & 0.3904 & 2.6 & 5.707 & 7.3 & 1.783 \\
4 & 21, Caucasian & 0.3416 & 2.28 & 5.824 & 7.15 & 1.592 \\
& 39, Caucasian & 0.2786 & 1.86 & 4.828 & 8.63 & 1.076 \\
5 & 20, Caucasian & 0.2387 & 1.59 & 5.411 & 7.7 & 1.033 \\
& 30, Caucasian & 0.1478 & 0.985 & 6.851 & 6.08 & 0.81 \\
& 24, Caucasian & 0.2704 & 1.8 & 5.670 & 7.35 & 1.227 \\
& 42, Caucasian & 0.2364 & 1.58 & 6.336 & 6.58 & 1.198 \\
& 25, Caucasian & 0.2710 & 1.81 & 6.333 & 6.58 & 1.373 \\
\hline
\end{tabular}

Flux (J); Permeation coefficient (P); Lag Time (Tlag); Diffusion coefficient (D); Partition Coefficient (K).

\section{Statistical analysis}

The statistical significance of the data $(p<0.05)$ was computed with a one-way ANOVA, and the software used was Statistica ${ }^{\circledR}$.

\section{RESULTS AND DISCUSSION}

The reduction in side effects, improving patient compliance, and avoiding hepatic first-pass metabolism are some of the advantages of the transdermal therapeutic systems. The ability of the drug to permeate the skin, in particular the stratum corneum is mostly affected by the chemical enhancers that may increase transdermal and topical delivery (Barry, 2001).

The results corresponding to the parameters of permeation were presented at Table II, as the average of each duplicate experiment and the range of the considered values.

Possible differences in the mean level of response produced by different treatments (formulation) or in the degree of variation of the data were determined by the statistical analyses.

Tables III to VIII showed the one-way ANOVA for the permeation parameters of flux, permeability and Lag Time for all formulations (treatment). Tables III, V and VII expressed the analyses of variance. The values described for flux and permeation coefficient presented an important significance level. It was not possible to obtain any significant difference between lag time values. The Tables IV, VI and VIII expressed the multiple range analysis for permeation parameters by formulations (treatments).

TABLE III - ANOVA one-way for formulation (treatment) and flux.

\begin{tabular}{lccccc}
\hline & $\begin{array}{c}\text { Sum of } \\
\text { squares }\end{array}$ & $\begin{array}{c}\text { Degrees of } \\
\text { freedom }\end{array}$ & $\begin{array}{c}\text { Mean } \\
\text { square }\end{array}$ & F-ratio & $\begin{array}{c}\text { Significance } \\
\text { level }\end{array}$ \\
\hline Effect & 0.037406 & 4 & 0.009351 & 2.731007 & 0.097025 \\
Error & 0.030818 & 9 & 0.003424 & & \\
\hline
\end{tabular}

TABLE IV - Multiple range comparison procedure for flux by formulation (treatment) by Tukey test

\begin{tabular}{lccccc}
\hline $\begin{array}{l}\text { Treatment } \\
\text { (formulation) }\end{array}$ & $\{1\}$ & $\{2\}$ & $\{3\}$ & $\{4\}$ & $\{5\}$ \\
\hline $1\{1\}$ & 0.2221333 & 0.1870500 & 0.3368667 & 0.2189667 & 0.2186667 \\
$2\{2\}$ & 0.527764 & 0.527764 & $0.039809^{*}$ & 0.948605 & 0.943746 \\
$3\{3\}$ & $0.039809^{*}$ & $0.020557^{*}$ & $0.020557^{*}$ & 0.564909 & 0.568504 \\
$4\{4\}$ & 0.9348605 & 0.564909 & $0.035709^{*}$ & $0.035709^{*}$ & 0.035343 \\
$5\{5\}$ & 0.943746 & 0.568504 & $0.035343^{*}$ & 0.995127 & 0.995127 \\
\hline
\end{tabular}

*denotes a statistically significant difference. 
TABLE V - Analysis of variance table for formulation (treatment) and permeability $\left(\mathrm{cm}^{2} / \mathrm{h}\right)$, one-way factorial design .

\begin{tabular}{lccccc}
\hline & $\begin{array}{c}\text { Sum of } \\
\text { squares }\end{array}$ & $\begin{array}{c}\text { Degrees of } \\
\text { Freedom }\end{array}$ & $\begin{array}{c}\text { Mean of } \\
\text { squares }\end{array}$ & F-ratio & $\begin{array}{c}\text { Significance } \\
\text { Level }\end{array}$ \\
\hline Effect & 1.668464 & 4 & 0.417113 & 2.732013 & 0.096948 \\
Error & 1.374094 & 9 & 0.152677 & & \\
\hline
\end{tabular}

TABLE VI - Multiple range analysis for permeability $\left(\mathrm{cm}^{2} / \mathrm{h}\right)$ by formulation (treatment), one-way factorial design.

\begin{tabular}{lccccc}
\hline $\begin{array}{l}\text { Treatment } \\
\text { (formulation) }\end{array}$ & $\{1\}$ & $\{2\}$ & $\{3\}$ & $\{4\}$ & $\{5\}$ \\
\hline $1\{1\}$ & 1.480000 & 1.245000 & 2.246667 & 1.45833 & 1.460333 \\
$2\{2\}$ & & 0.526501 & $0.039698^{*}$ & 0.947340 & 0.952194 \\
$3\{3\}$ & 0.526501 & & $0.020437^{*}$ & 0.564529 & 0.560954 \\
$4\{4\}$ & $0.039698^{*}$ & $0.020437^{*}$ & & $0.035513^{*}$ & $0.035880^{*}$ \\
$5\{5\}$ & 0.947340 & 0.564529 & $0.035513^{*}$ & & 0.995135 \\
\hline
\end{tabular}

*denotes a statistically significant difference.

TABLE VII - Analysis of variance table for formulation (treatment) and Lag Time, one-way factorial design.

\begin{tabular}{lccccc}
\hline & $\begin{array}{c}\text { Sum of } \\
\text { squares }\end{array}$ & $\begin{array}{c}\text { Degrees of } \\
\text { Freedom }\end{array}$ & $\begin{array}{c}\text { Mean of } \\
\text { squares }\end{array}$ & F-ratio & $\begin{array}{c}\text { Significance } \\
\text { level }\end{array}$ \\
\hline Effect & 42.57146 & 4 & 10.64286 & 4.143432 & 0.035637 \\
Error & 23.11750 & 9 & 2.56861 & & \\
\hline
\end{tabular}

TABLE VIII - Multiple range analysis for Lag Time by formulation (treatment), one-way factorial design

\begin{tabular}{lccccc}
\hline $\begin{array}{l}\text { Treatment } \\
\text { (formulation) }\end{array}$ & $\{1\}$ & $\{2\}$ & $\{3\}$ & $\{4\}$ & $\{5\}$ \\
\hline $1\{1\}$ & 10.04739 & 7.78327 & 5.453519 & 5.978027 & 5.9719656 \\
$2\{2\}$ & & 0.156476 & $0.0066138^{*}$ & $0.012524^{*}$ & $0.012431^{*}$ \\
$3\{3\}$ & 0.156476 & & 0.145445 & 0.247993 & 0.246526 \\
$4\{4\}$ & $0.006613^{*}$ & 0.145445 & & 0.697902 & 0.701201 \\
$5\{5\}$ & $0.012524^{*}$ & 0.247993 & 0.697902 & & 0.996400 \\
\hline
\end{tabular}

*denotes a statistically significant difference.

The statistical analysis of the flux (Figure 1) showed that there was an important difference between the Papain $0.2 \%$ formulation and the other formulations. This could be an indication that papain acted like a penetration enhancer more effectively.

The permeation coefficient (Figure 2) confirmed that papain $0.2 \%$ enhanced the permeation of DS through the skin. The plot showed an increased in the mean values of formulation 3, confirming enhancer characteristic of papain.

The Lag Time statistical analyses (Figure 3 ) showed statistical differences between the Papain $0.2 \%$ and other formulations, with pequi oil $5 \%$ having the greatest Lag
Time values. These data confirmed, once more, that formulation containing papain $0.2 \%$ was the best enhancer for the DS permeability.

As the lag time method was used, the precision of the values of J and Lag Time when combined with the thickness of the barrier resulted in significant errors in the estimation of $\mathrm{D}$ and $\mathrm{K}$. Thus, the parameters $\mathrm{D}$ and $\mathrm{K}$ are only effective and realistic for use in observation of the mechanism of diffusion or the structure of the membrane. Therefore, a mass transfer coefficient such as the permeability coefficient is more useful to the interpretation of this phenomena (Shah, 1993). 


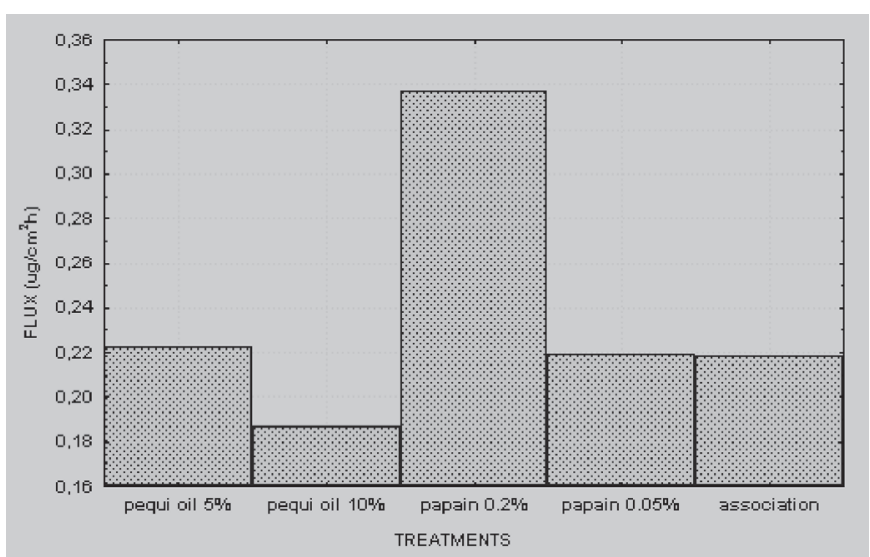

FIGURE 1 - Plot of means of Flux $\left(\mu \mathrm{g} / \mathrm{cm}^{2} \mathrm{~h}\right)$ in function of treatments (formulations).

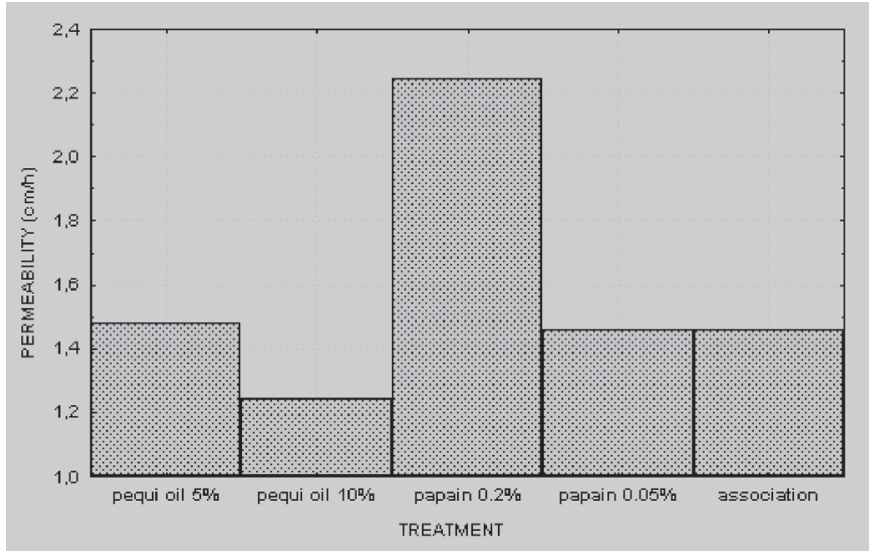

FIGURE 2 - Plot of means of permeability $\left(\mathrm{cm}^{2} / \mathrm{h}\right)$ in function of treatments (formulations).

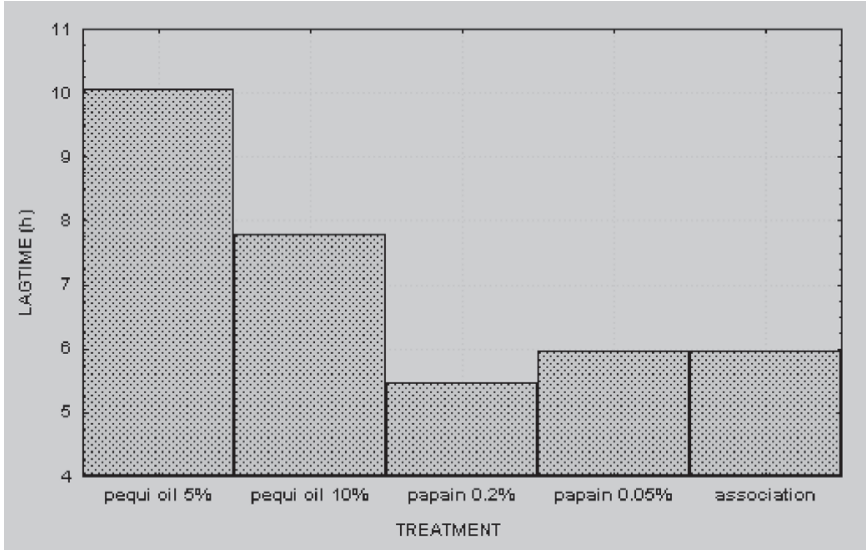

FIGURE 3 - Plot of means of Lag Time (h) in function of treatments (formulations).

The diffusion coefficient also indicated that papain $0.2 \%$ had the best results as an enhancer. Conversely, the partition coefficient data did not show any statistical difference between any of the formulations, a consistent result with the above related facts.

The fluid receptor used was modified Earle's medium (MEM) with gentamicin $50 \mathrm{mg} / \mathrm{mL}$, described elsewhere. The MEM is a very rich medium, used for cell culture and creates interference in HPLC analysis. In order to remove this interference, in each experiment, a standard profile was performed and $\mathrm{R}^{2}$ values between 0.9771 and 1 were obtained (Lopes et al., 2003).

In 1989, Goodman and Barry suggested that an effective penetration enhancer should interact with both intercellular and transcellular corneum components. To activate this situation we used a combination of enhancers, papain $0.1 \%$ and pequi oil $7.5 \%$, expected to act by different mechanisms (Goodman, Barry, 1989).

The flux, permeability coefficient and Lag Time profiles of this formulation demonstrated a behavior very similar to that of papain $0.05 \%$, probably indicating that the enhancer concentrations were not optimized.

Finally, when the data from the pre-treatment (data not shown) were observed, the partition coefficient values were higher than those for the formulations. These facts have been demonstrated in literature (Goodman, Barry, 1989) and may also suggest that the gel formulations retained DS, blocking its penetration. This result is corroborated by Özgüney and co-workers (2006) and Escribano and co-workers (2003) that observed that DS was easily released from microemulsions and liquid formulations in comparison with gels.

Figure 4 reported the in vitro permeation profiles of DS with papain and pequi oil through human skin. A linear relationship was obtained when the total amount of DS $/ \mathrm{cm}^{2}$ in the receptor phase was plotted against time, indicating that the human skin is permeable to DS and that percutaneous transport can be described by zero order kinetics.

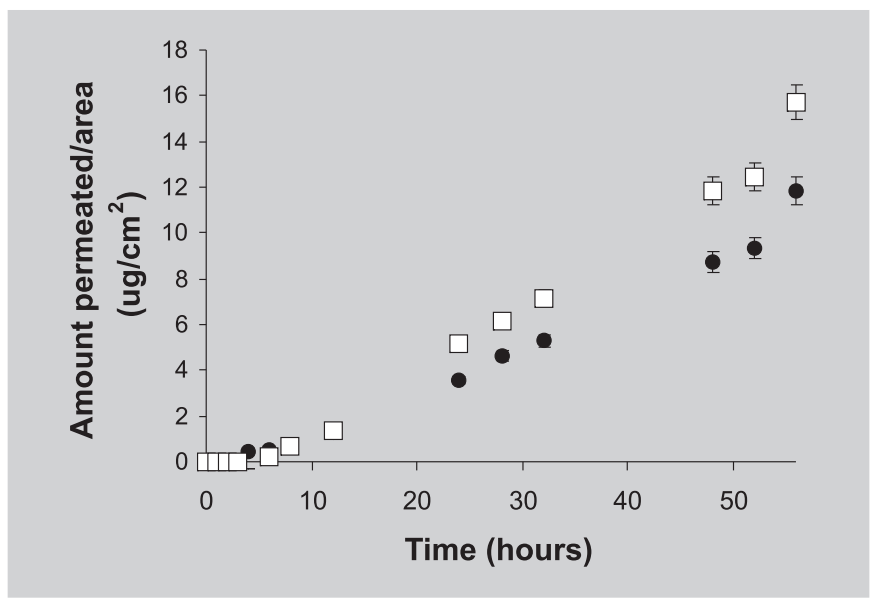

FIGURE 4 - In vitro permeation profile of DS with two different enhancers: $(\square)$ papain $0.2 \%$; $(\bullet)$ pequi oil $5 \%$. 
Diffusion profiles achieved using the Franz cell indicate that papain $0.2 \%(\mathrm{w} / \mathrm{v})$ was the best permeation enhancer for diclofenac sodium across human skin (the data obtained are presented in Table II).

Although pequi oil (PO) is rich in oleic acid (about $50 \%$ ), it was not efficiently enough on DS permeation, probably due to its low concentration in the formulation. Adjust must be done to improve its enhancer effect, raising final concentration or even changing the basic formulation. Probably an emulsion could be more effective to delivery when enriched with pequi oil and this component could also act as an emollient agent.

\section{CONCLUSIONS}

The results of this research work showed that papain could be a good candidate as a penetration enhancer to delivery of drugs through the skin. Moreover, a combination of pequi oil and papain presented better enhancer performance than isolated pequi oil in the formulations analyzed.

\section{ACKNOWLEDGMENTS}

We are grateful to Dr. Shunji Kitagawa (Niigata University of Pharmacy and Applied Life Sciences, Niigata College of Pharmacy) for the cell diffusion donation, to Dr. Shinji Sato (Niigata University of Pharmacy and Applied Life Sciences, Faculty of Applied Life Sciences) for analyzing experimental data and to Novartis for donating the Diclofenac Sodium reference substance. This work was supported by the master fellowship from National Council for Scientific and Technological Development (CNPq), foundation linked to the Ministry of Science and Technology (MCT) to support Brazilian research, and by Sumitomo Mitsui, Bunka Fund of Research award and CAPES.

\section{RESUMO}

\section{Avaliação in vitro da papaína e do óleo de pequi como promotores de permeação cutânea para diclofenaco de sódio em pele humana}

O objetivo desta pesquisa foi determinar in vitro o potencial da papaína e do óleo de pequi como promotores de penetração cutânea para o diclofenaco de sódio (DS) através de pele humana. Os estudos de penetração foram conduzidos em células de difusão vertical. Os promotores foram associados ou não em géis em concentrações distintas. A avaliação in vitro revelou que a papaína $0,2 \% \mathrm{p} /$ $p$ apresentou propriedade promotora maior para o diclofenaco de sódio $\left(J=0,3369 \mu \mathrm{g} / \mathrm{cm}^{2} x\right.$ h). O óleo de pequi $10,0 \% \mathrm{p} / v$ promoveu redução do fluxo $(\mathrm{J}=0,1848$ $\mu \mathrm{g} / \mathrm{cm}^{2} x \mathrm{~h}$ ) e a combinação de ambos os promotores apresentou valor mediano de fluxo de $J=0,2187 \mu \mathrm{g} / \mathrm{cm}^{2} x \mathrm{~h}$. A partir dos resultados, verificou-se que a papaína exerceu ação promotora de penetração cutânea melhor que o óleo de pequi

UNITERMOS: Papaína/ avaliação in vitro. Óleo de Pequi/avaliação in vitro. Permeação cutânea in vitro/promotores. Diclofenaco de sódio/penetração cutânea.

\section{REFERENCES}

BABY,A.R.; MIGLIATO, K.F.; MACIEL, C.P.M.;ZAGUE, V.; PINTO, C.A.S.O.; SALGADO, H.R.N.; KANEKO, T.M.; VELASCO, M.V.R. Accelerated chemical stability data of $\mathrm{O} / \mathrm{W}$ fluid emulsions containing the extract of Trichilia catigua Adr. Juss (and) Ptychopetalum olacoides Bentham. Rev. Bras. Cienc. Farm., São Paulo, v.43, n.4, p.405-412, 2007.

BARRY, B.W. Novel mechanisms and devices to enable successful transdermal drug delivery. Eur. J. Pharm. Sci., Amsterdam, v.14, n.2, p.101-114, 2001.

ESCRIBANO, E.; CALPENA, A.C.; QUERALT, J.; OBACH, R.; DOMENECH, J. Assessment of diclofenac permeation with different formulations: anti-inflammatory study of a selected formula. Eur. J. Pharm. Sci., Amsterdam, v.19, n.4, p.203-210, 2003.

GOODMAN, M.; BARRY, B.W. Lipid-protein-partitioning (LPP) theory of skin enhancer activity: finite dose technique. Int. J. Pharm., Amsterdam, v.57, n.1, p.29-40, 1989.

LOPES, P.S.; KANEKO, T.M.; TAKANO, C.Y.; LACERDA, A.C.L.; LATORRE, L.R.; KATO, M.J. Determination of diclofenac sodium in Eagle's Minimum Essential Medium with Earle's Balanced Salt Solution. $J$. AOAC Int., Gaithersburg, v.86, n.4, p.681-684, 2003.

NISHIHATA, T.; KAMADA, A.; SAKAI, K.; TAKAHASHI, K.; MATSUMOTO, K.; SHINOZAKI, K.; TABATA, Y.; KEIGAMI, M.; MIYAGI, T.; TATSUMI, N. Percutaneous absorption of diclofenac in rats and humans: aqueous gel formulation. Int. J. Pharm., Amsterdam, v.46, n.1-2, p.1-7, 1988. 
ÖZGÜNEY, I.S.; KARASULU, H.Y.; KANTARCI, G.; SÖZER, S.; GÜNERI, T.; ERTAN, G. Transdermal delivery of diclofenac sodium through rat skin from various formulations. AAPS PharmSciTech, Arlington, v.7, n.4, pE1-E7, 2006. Disponível em: $<$ http:// www.aapspharmscitech.org/articles/pt0704/pt070488/ pt070488.pdf $>$. Acesso em: 04 set. 2007.

PINTO, C.A.S.O.; GREEN, D.; BABY, A.R.; RUAS, G.W.; KANEKO, T.M.; MARANA, S.R.; VELASCO, M.V.R. Determination of papain activity in topical dosage forms: single laboratory validation assay. Lat. Am. J. Pharm., Buenos Aires, v.26, n.5, p.771-775, 2007.

QUINTANAR-GUERREIRO,D.; GANEN-QUINTANAR, A.; TAPIA-OLGUÍN, P.; KALIA, Y.N.; BURI, P. The effect of keratolytic agents on the permeability of three imidazole antimycotic drugs through the human nail. Drug. Dev. Ind. Pharm., Philadelphia, v.24, n.7, p.685690, 1998.
ROLIM, A.; OISHI, T.; MACIEL, C.P.M.; ZAGUE, V.; PINTO, C.A.S.O.; KANEKO, T.M.; CONSIGLIERI, V.O.; VELASCO, M.V.R. Total flavonoids quantification from $\mathrm{O} / \mathrm{W}$ emulsion with extract of Brazilian plants. Int. J. Pharm., Amsterdam, v.308, n.1-2, p.107-114, 2006.

SHAH, J.C. Analysis of permeation data: evaluation of the lag time method. Int. J. Pharm., Amsterdam, v.90, n.2, p.161169, 1993.

SHAH, J.C.; KAKA, I.; TENJARLA, S.; LAU, S.W.J.; CHOW, D. Analysis of percutaneous permeation data: II. Evaluation of the lag time method. Int. J. Pharm., Amsterdam, v.109, n.3, p.283-290, 1994.

Recebido para publicação em 31 de julho de 2007 Aceito para publicação em 03 de dezembro de 2007 